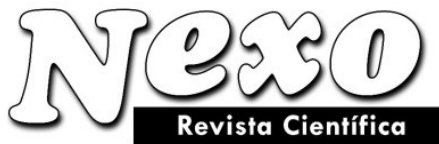

ISSN-E 1995-9516

Universidad Nacional de Ingeniería http://revistas.uni.edu.ni/index.php/Nexo http://dx.doi.org/10.5377/nexo.v31i01.6453

Vol. 31, No. 01, pp. 47-63/Junio 2018

(c) (i) $(9)$

\title{
THE RISK CAUSED BY HYDROCARBON SPILLS IN THE EASTERN REGION OF THE CANARY ISLANDS WATERS: TESEO MODEL AND SIROCO SYSTEM
}

\section{RIESGO DERIVADO POR VERTIDOS DE HIDROCARBUROS EN LA REGIÓN ORIENTAL DE LAS AGUAS CANARIAS: MODELO TESEO Y SISTEMA SIROCO}

\author{
J.M. Calvilla*, J.R. Bergueiro, J.I. Gómez, J.A. González, E. Calvilla \\ Universidad de La Laguna (Grupo I+D CONSEMAR) \\ jmcalvi@ull.edu.es
}

(recibido/received: 11-11-2017; aceptado/accepted: 01-06-2018)

\begin{abstract}
In view of the increasing oil interest shown by Spain and Morocco, the aim of this project is to test the risk of hypothetical spills of hydrocarbons in the eastern region of the Canary Islands waters and their surroundings through the Simulation Model of Hydrocarbon Transport (TESEO) and the Island Response and Operations System against Ocean Pollutants, in Spanish Sistemas Insulares de Respuesta y Operaciones Ante Contaminantes Oceánicos (SIROCO).

Palabras clave: Oil Spill; SIROCO; TESEO

\section{RESUMEN}

En este trabajo se analizan a través del Modelo de Simulación de Transporte de Hidrocarburos (TESEO) y los Sistemas Insulares de Respuestas y Operaciones ante Contaminantes Oceánicos (SIROCO) el riesgo derivado de hipotéticos vertidos de hidrocarburos en la región oriental de las aguas canarias y sus proximidades ante el reciente interés petrolífero en la zona por parte de España y Marruecos.
\end{abstract}

Keywords: Derrame de petróleo; SIROCO; TESEO 


\section{INTRODUCTION}

The core of the oceanic operational system consists of two elements: observing services and dynamic models with data assimilation. The appliances of this system are countless and they have prompt scientific, technological and socio-economic benefits. Optimal strategies against marine pollution (LCC) are set out to trace and analyse the progression of spills through the oceanographic operational system, at both regional and local level. The developed appliances are equally useful to predict floating objects and shipwrecks. The integrated systems are also useful for the integrated management at coastal zones, maritime transport, port engineering and the management of fish resources, through physical variables predictions, both meteorological and oceanographic, that are the basis of chemical-biological models.

The ESEOO Project (Establishment of an Oceanographic Operational Spanish System) provides essential information to respond to emergency situations by accidental polluting spills and allows addressing these critical situations in the best possible way. The oceanographic operational system consists of a range of services based on numerical modelling and oceanographic data analysis, both historical and live data. The Simulation Model of Hydrocarbon Transport (TESEO) can simulate the transport and degradation of hydrocarbons. The structure of the TESEO operational system is as shown in Figure 1.

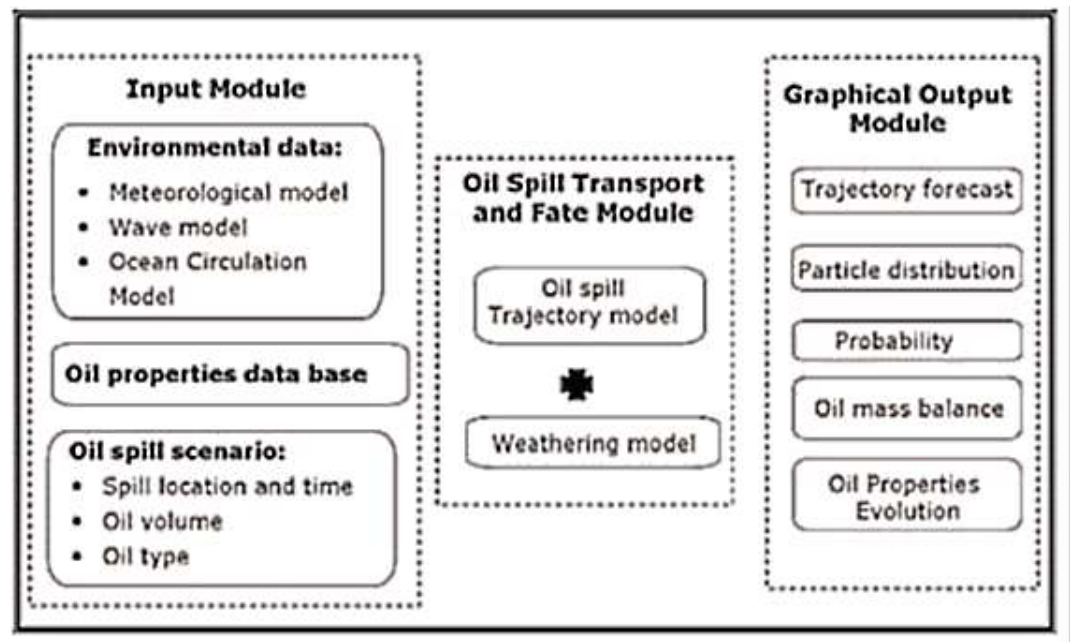

Figure 1 - Operational Structure of the TESEO Model.

Source: (ABASCAL, 2008).

The drifting model is a two-dimensional Lagrangian Model, which simulates the movement and degradation of a hydrocarbon, considering the spill as the sum of particles that move separately, due to strengths such as wind, waves, current and turbulent diffusion.

The model has been calibrated using the algorithm SCE-UA (Shuffled Complex Evolution Method University of Arizona) and adapted for its application in Oceanography (ABASCAL, 2008).

The calibration using drifting oceanographic buoys enables to optimize the algorithm (Figure 2) and obtain ratios which reduce the differences between the real movement of the spill and the numerical prediction. The optimization method pursues the calibration of the predictive Lagrangian Transport Model. The objective of the calibration is to find the value of the coefficients that minimize the objective function.

$$
J=\sum_{t} \sum_{i=1}^{N}\left[\left(U_{B x}(x, t)-U_{M x}(x, t, \theta)\right)^{2}+\left(U_{B y}(x, t)-U_{M y}(x, t, \theta)\right)^{2}\right] ; \theta\left(C_{D}, C_{C}\right)
$$


where:

$\mathrm{N}$ : Buoys number

$U_{B}$ : Buoys velocity

$$
U_{B}=\frac{x_{f}-x_{0}}{\Delta t}
$$

$U_{M}:$ Velocity (wind, wave, current)

$$
\begin{aligned}
& U_{M x}(t)=C_{H} U_{\text {olax }}+C_{D} U_{\text {vientox }}+C_{C} U_{\text {corrientex }} \\
& U_{M y}(t)=C_{H} U_{\text {olay }}+C_{D} U_{\text {vientoy }}+C_{C} U_{\text {corrientey }}
\end{aligned}
$$

$C_{D}$ : wind drag coefficient

$C_{H}$ : wave coeffcient

$C_{C}$ : current coefficient (opcional)
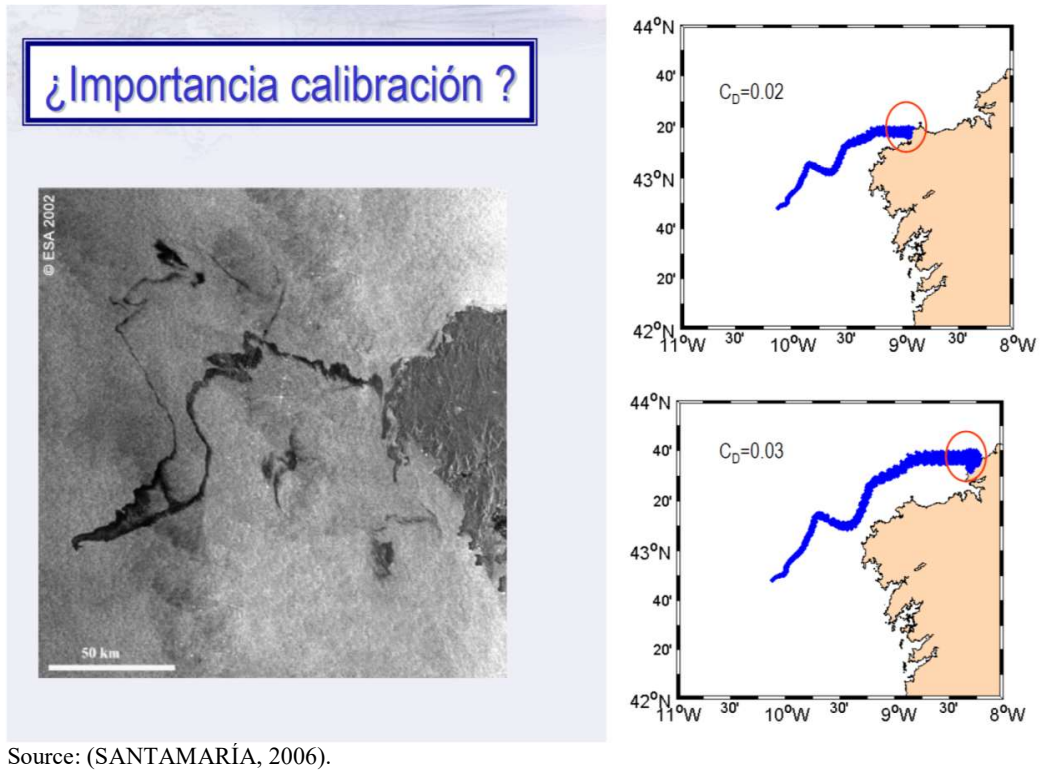

Figure 2 - Calibration TESEO Model (Prestige).

The application has two operating modes called operational and re-test mode. The re-test mode can manage the forcing files and control the parameters of implementation of the model. The system consists of three modules: the input module, the Oil Spill Transport and Fates module and the Graphical Output module. Each module is integrated in a simple graphical user interface (GUI), which provides efficient information on the ability to manage oil spills and respond to them (ABASCAL, 2008).

The results obtained are analysed through the Island Response and Operations System against Ocean Pollutants (SIROCO) (Figure 3) as a comprehensive managing tool for the analysis, planning, mobilisation and support in decision-making of the human resource and the material resources against pollution with the aim of preventing or minimizing the pollution effects in the affected áreas (BERGUEIRO, J.R. et al., 2001) (BERGUEIRO, 2004) (BERGUEIRO, 2009). 


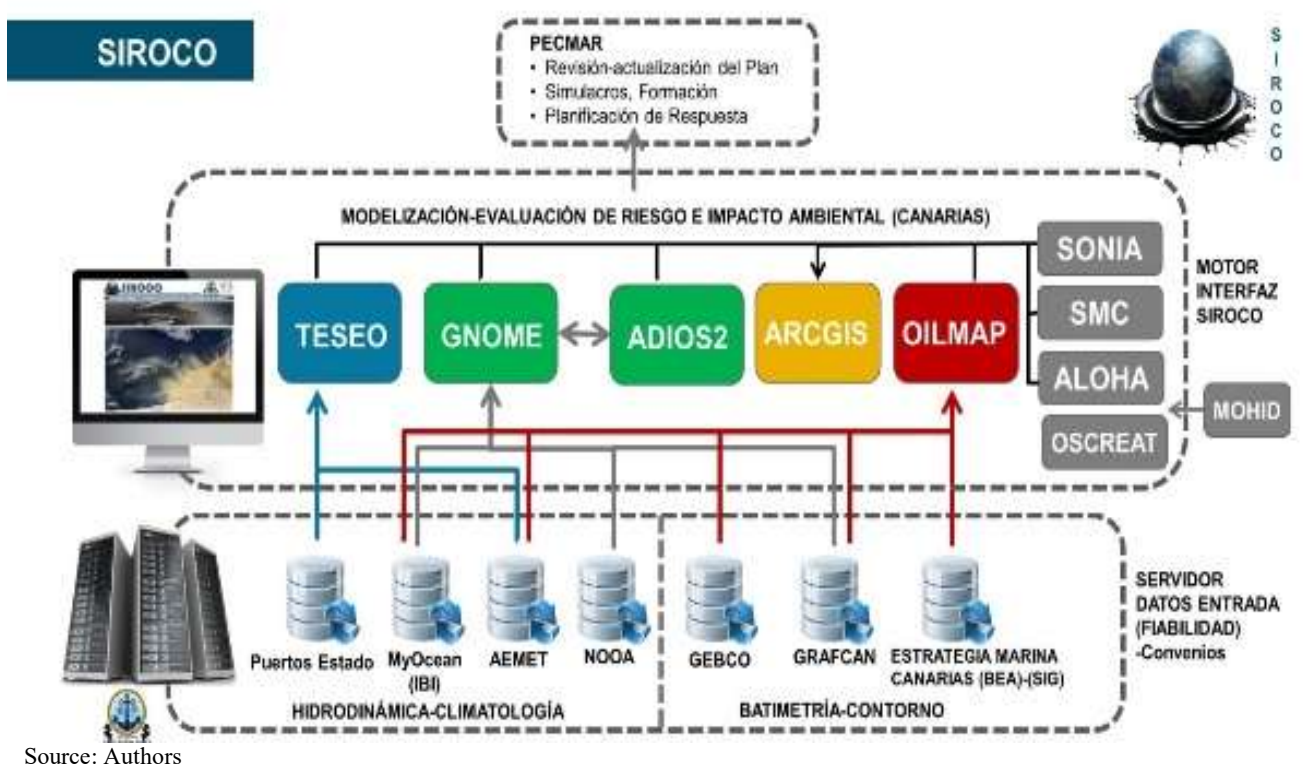

Figure 3: SIROCO Model.

\section{METHODOLOGY}

\subsection{Input Model}

The relevant event data, the forcing data and the selection of the type of spill are entered in the TESEO System input module. The interface allows remote control (FTP) to different operational predictive systems and the data can be introduced in NETCDF format (Figure 4).

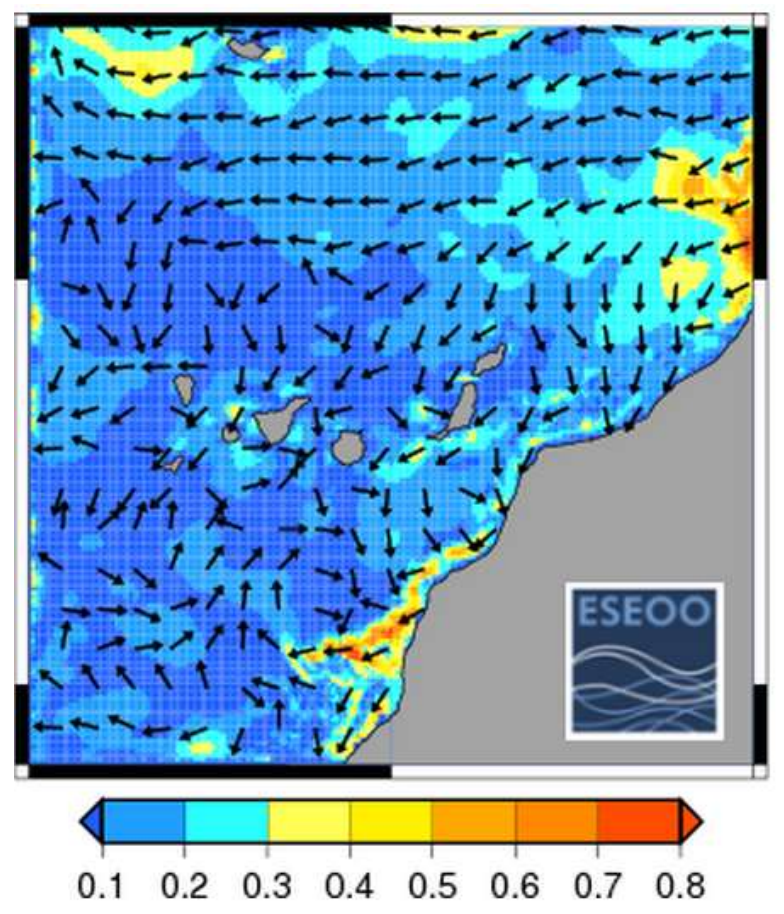

Source: Puertos de Estado (State Ports). ESEOO Project.

Figure 4- Speed $(\mathrm{m} / \mathrm{s})$ and direction of surface currents (00 H GMT 02/10/2014). 


\subsection{Oil Spill Transport and Fate Module}

The transport model takes into consideration the influence of weathering processes on the evolution of the spill. The drift processes are described by approaching to a multiparticle system, based on the PICHI model developed by the University of Cantabria after the Prestige oil spill (2002). The Table 1 shows the equations used in TESEO model [Fay (1969, 1971); Lehr et al. (1984); Stiver and MacKay (1984); MacKay (1980)].

Table 1: Equations used in TESEO model.

\begin{tabular}{|c|c|}
\hline Magnitude & Equation \\
\hline $\begin{array}{l}\text { Particle } \\
\text { position }\end{array}$ & $\frac{d \vec{x}}{d t}=\vec{u}_{a}\left(\vec{x}_{i}, t\right)+\vec{u}_{d}\left(\vec{x}_{i}, t\right)$ \\
\hline $\begin{array}{l}\text { Advective } \\
\text { velocity }\end{array}$ & $\overrightarrow{\boldsymbol{u}}_{\boldsymbol{a}}=\overrightarrow{\boldsymbol{u}}_{c}+C_{D} \overrightarrow{\boldsymbol{u}}_{w}+C_{H} \overrightarrow{\boldsymbol{u}}_{H}$ \\
\hline $\begin{array}{l}\text { Turbulent } \\
\text { diffusion }\end{array}$ & $\left|\vec{u}_{d}\right|=\sqrt{\frac{6 D}{\Delta t}}$ \\
\hline $\begin{array}{l}\text { Evaporation } \\
\text { velocity }\end{array}$ & $\Delta F=\exp \left[6,3-\frac{10,3}{T}\left(T_{0}-T_{G} F\right)\right]\left(\frac{k A \Delta t}{V_{0}}\right)$ \\
\hline Emulsification & $\frac{d Y}{d t}=-k\left(W_{10}+1\right)^{2}\left(1-\frac{Y}{Y_{f}}\right)$ \\
\hline Density & $\rho=Y \rho_{w}+(1-Y) \rho_{0}\left(1-C_{T}\left(T-T_{0}\right)\right)\left(1+C_{F} F\right)$ \\
\hline Viscosity & $v_{f}=v_{0} \exp \left(\frac{C_{3} Y}{1-C_{4} Y}\right) \exp \left[C_{5}\left(T-T_{0}\right)\right] \exp \left(C_{6} F\right)$ \\
\hline
\end{tabular}

Where: $\overrightarrow{\boldsymbol{u}}_{\boldsymbol{a}}$ advection velocity; $\overrightarrow{\boldsymbol{u}}_{\boldsymbol{d}}$ diffusion velocity; $\overrightarrow{\boldsymbol{u}}_{\boldsymbol{c}}$ current velocity; $\overrightarrow{\boldsymbol{u}}_{\boldsymbol{w}}$ wind velocity; $\overrightarrow{\boldsymbol{u}}_{\boldsymbol{H}}$ Stokes drift; A Spill Area; $\boldsymbol{V}_{\mathbf{0}}$ Volume; T Tempreature; $\boldsymbol{T}_{\mathbf{0}}, \boldsymbol{T}_{\boldsymbol{G}}$ son las constantes de destilación; $\boldsymbol{W}_{\mathbf{1 0}}$ wind velocity (10 m); $\boldsymbol{Y}_{\boldsymbol{f}}$ maximum water content in oil.

\subsection{Graphical Output Module}

The results of the numerical simulation are shown in this section and they are represented in five different types of graphics: the positions of the centre of gravity, distribution of particles, probability maps, mass balance and evolution of the hydrocarbon characteristics.

- The positions of the centre of gravity: It represents the position of the centre of gravity, meaning the central position of the cloud of particles in the course of time.

- Graphic of particles: These graphics represent the distribution of particles at a given time. The programme shows a map of particles every hour.

- Probability maps: These graphics show the chance of finding a spill or a floating object in an area and at a given time.

- Mass balance. TESEO generates the following graphics:

○ Evaporation (\%): hydrocarbon evaporation percentage.

- Evaporation $(\mathrm{t})$ : tonnes of evaporated hydrocarbon

- Hydrocarbon in the water (\%): percentage of hydrocarbon that remains in the water.

- Hydrocarbon in the water $(\mathrm{t})$ : tonnes of hydrocarbon that remain in the water.

- Hydrocarbon on land (\%): percentage of hydrocarbon that has reached land.

- Hydrocarbon on the ground $(\mathrm{t})$ : tonnes of hydrocarbon that have reached land.

- Product in the water $(\mathrm{t})$ : tonnes of emulsifying product (hydrocarbon plus water)

- Product on land $(\mathrm{t})$ : tonnes of emulsifying product (hydrocarbon plus water) that have reached land.

- Mass balance (t): this graphic shows simultaneously the evaporated hydrocarbon, the hydrocarbon that remains in the water and the one that reaches land (in tonnes). 
- Evolution of the hydrocarbon characteristics: the properties that can be represented are the density, the water volume and the viscosity.

The results obtained can be taken into consideration for the implementation of contingency plans and cleaning operations, both at sea and throughout the coast.

TESEO has been successfully tested as an operational tool at emergency actions in different oil spill simulation exercises carried out by Maritime Rescue (SASEMAR), in the Atlantic and the Mediterranean Sea. These experiences were the first attempt made in Spain to include operational systems to respond to hydrocarbon spills. The capacity of TESEO to use live data for the decision-making process was proved during the performance of the simulation. Comparing the predictions of the system with the track of the buoys, the results showed a high level of coincidence with the model behaviour (ABASCAL, 2008).

In order to get the best results from the path of the various spills, as well as to estimate the aging process of crude petroleum once it has been spilled into the water, a number of simulations have been carried out using the TESEO Model.

By comparing the results obtained from the simulations with any of the applied models, you can estimate the most likely path of a certain spill and how will its properties vary as it moves on the water surface and until it hits the coast. Besides that, you can obtain an average value of the quantity of hydrocarbon that has remained on the coast, where it hit.

\section{RESULTS AND DISCUSSIONS}

Several deterministic and stochastic cases have been analyzed .The following lines show the results obtained in a deterministic case from a hypothetical hydrocarbon spill in a region which has received significant interest from the oil industry. To conclude, a chart synthesizing various scenarios is attached.

\subsection{Region "Canarias-6” (TESEO)}

The project starts by analysing the region "Canarias-6". The input parameters to carry out the simulation are detailed in Table 2.

Table 2- Input parameters TESEO Model. Canarias 6 Region. Source: Own elaboration

\begin{tabular}{|c|c|c|}
\hline \multirow{2}{*}{ Spill location coordinates } & Longitude & Latitude \\
\hline & $13,41 \mathrm{~W}$ & $28,75 \mathrm{~N}$ \\
\hline Region & \multicolumn{2}{|c|}{ Canarias 6 (West border) } \\
\hline Type of oil & \multicolumn{2}{|c|}{ Arabian Ligth } \\
\hline Sea currents data & \multicolumn{2}{|c|}{ State ports } \\
\hline Wind data & \multicolumn{2}{|c|}{ AEMET } \\
\hline Water temperature & \multicolumn{2}{|c|}{$18^{\circ} \mathrm{C}$} \\
\hline Volume of spill & \multicolumn{2}{|c|}{$960.000 \mathrm{~L}$} \\
\hline Duration of spill & \multicolumn{2}{|c|}{ Instant } \\
\hline Simulation time & \multicolumn{2}{|c|}{72 hours } \\
\hline Diffusion coefficient $\left(\mathrm{m}^{2} / \mathrm{s}\right)$ & \multicolumn{2}{|c|}{50} \\
\hline
\end{tabular}

On the present simulation TESEO splits the path into three different sections. It is possible to observe date and time of the spill from each of them, as well as the moment when it hits the coast. Figure 5 shows the predicted path and the evolution this spill will take until it hits the coast of Fuerteventura. 


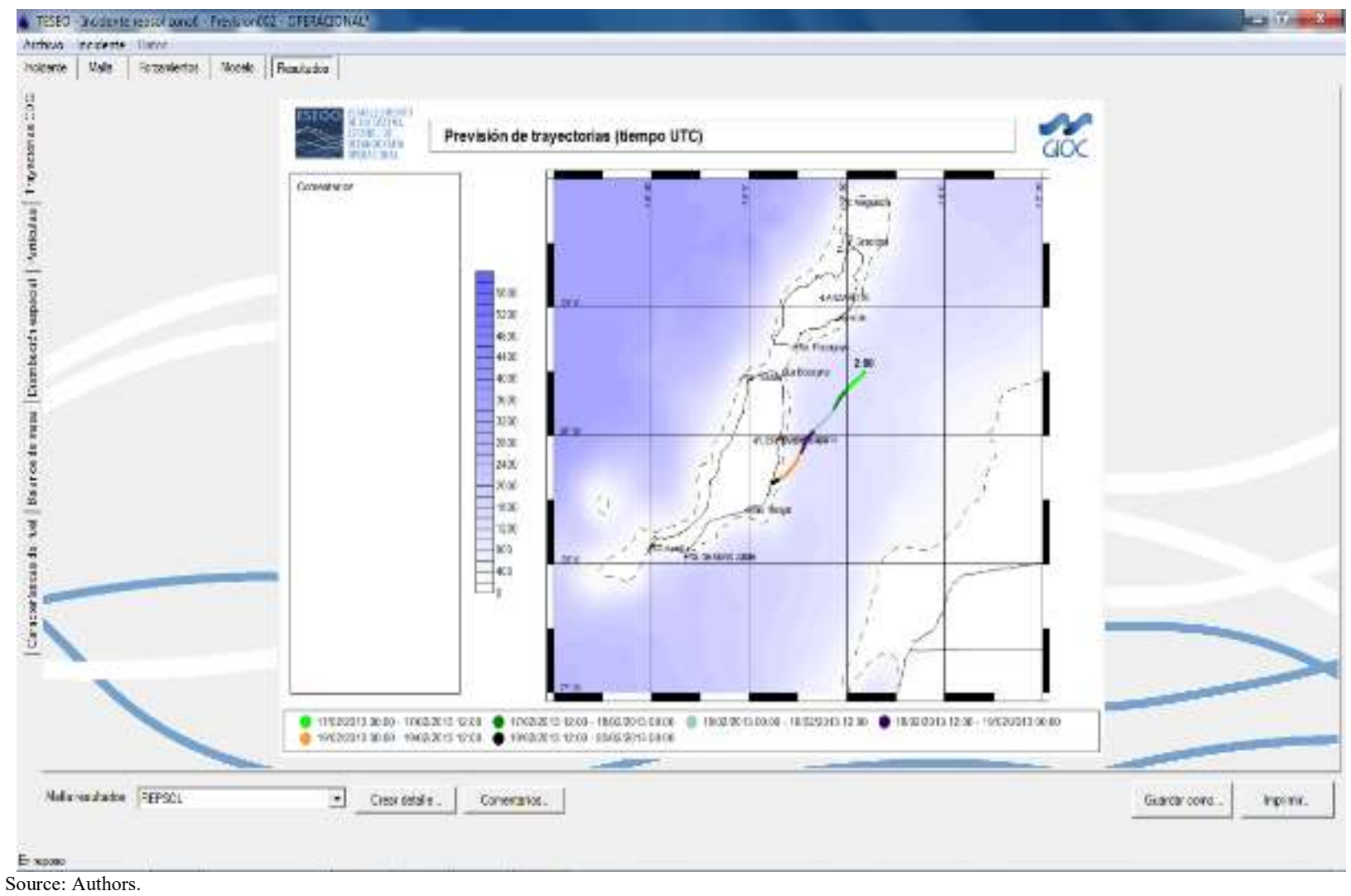

Figure ¡Error! No hay texto con el estilo especificado en el documento. - Path prediction of the oil spill. Canarias 6 Region. Teseo Model.

Figure 6 shows the location of the spill after 7 hours.

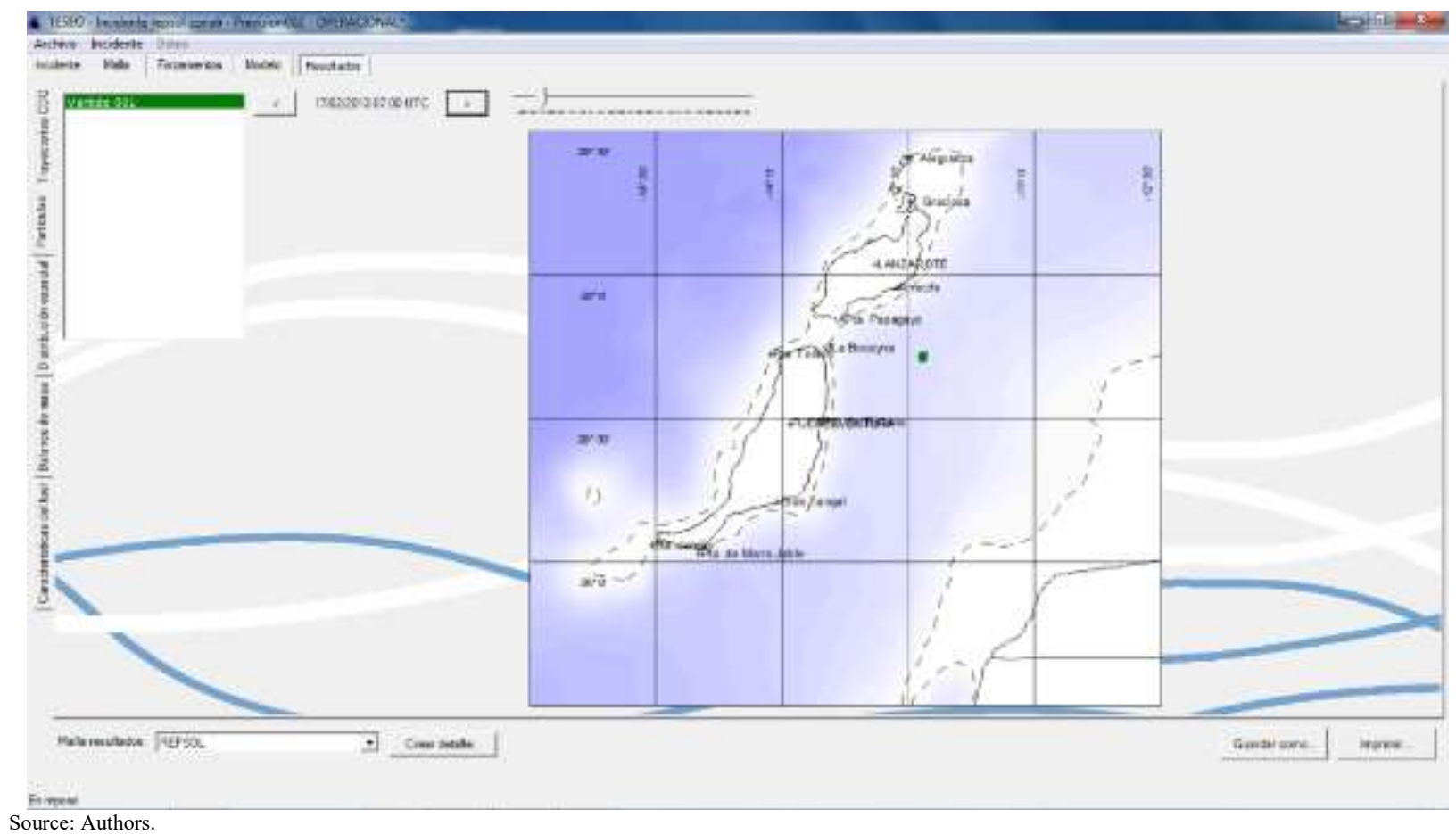

Figure 6: Spill location after 7 hours. Region Canarias 6. TESEO Model.

Nexo Revista Científica / Vol. 31, No. 01, pp. 47-63 / Junio 2018 
Figure 7 shows the location of the spill after 34 hours.

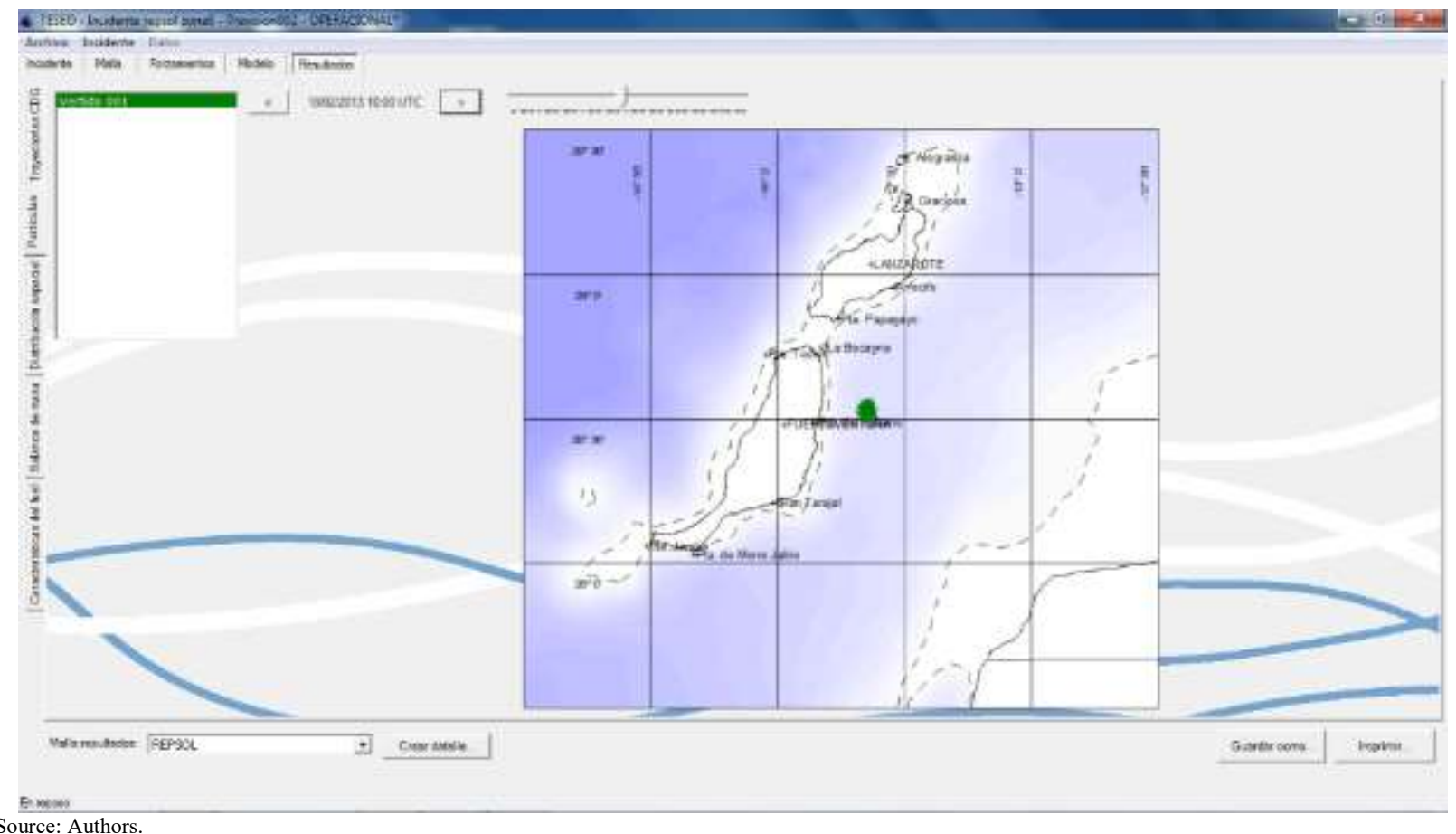

Source: Authors.

Figure 7: Spill location after 34 hours. Region Canarias 6. TESEO Model.

Figure 8 shows the location of the spill after 57 hours. At this point the mixture of hydrocarbons hits the coast of Lanzarote.

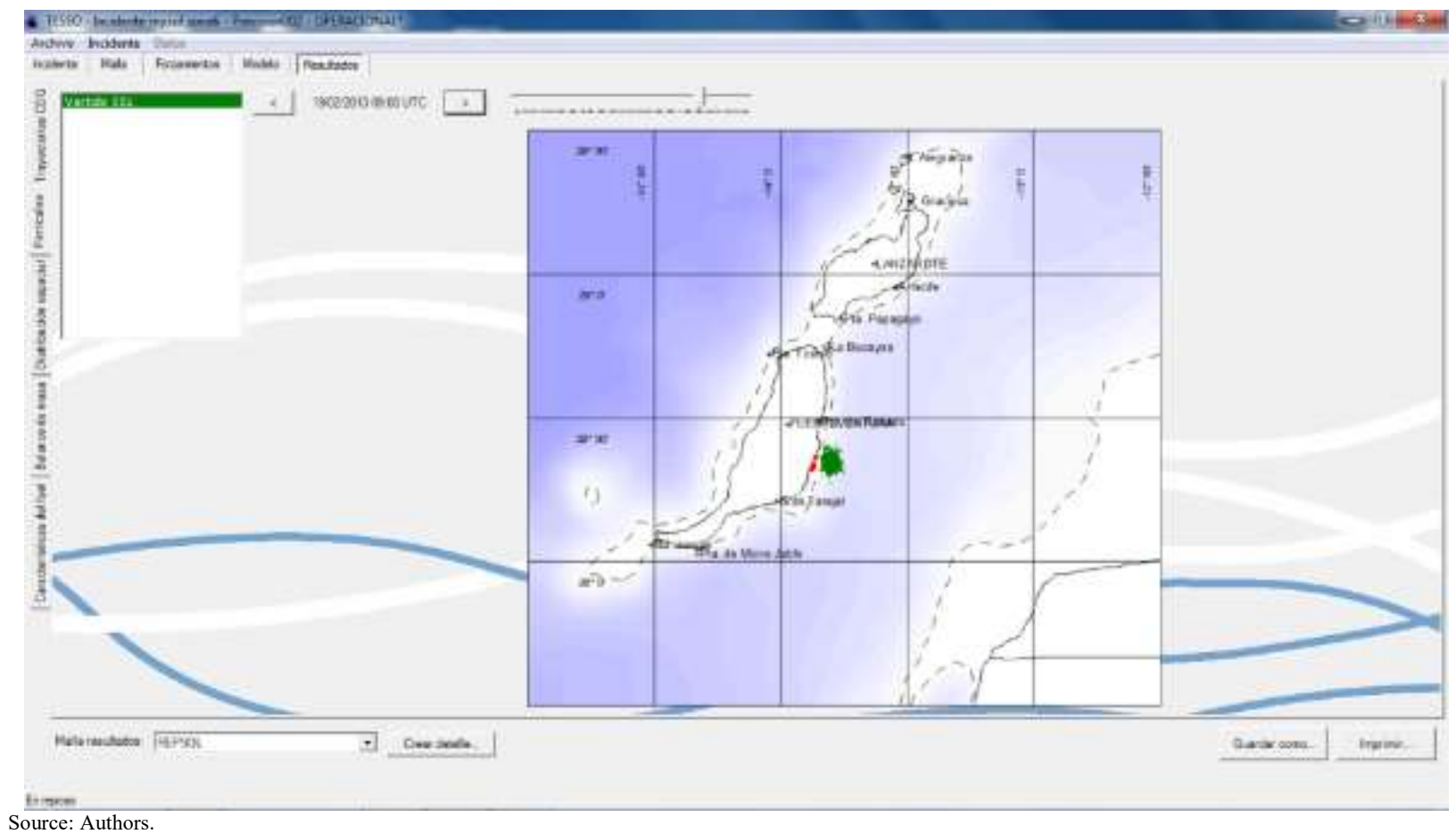

Nexo Revista Científica / Vol. 31, No. 01, pp. 47-63 / Junio 2018 
Figure 8: Spill location after 57 hours. Region Canarias 6. TESEO Model. The location of the spill after 72 hours is shown in Figure 9.

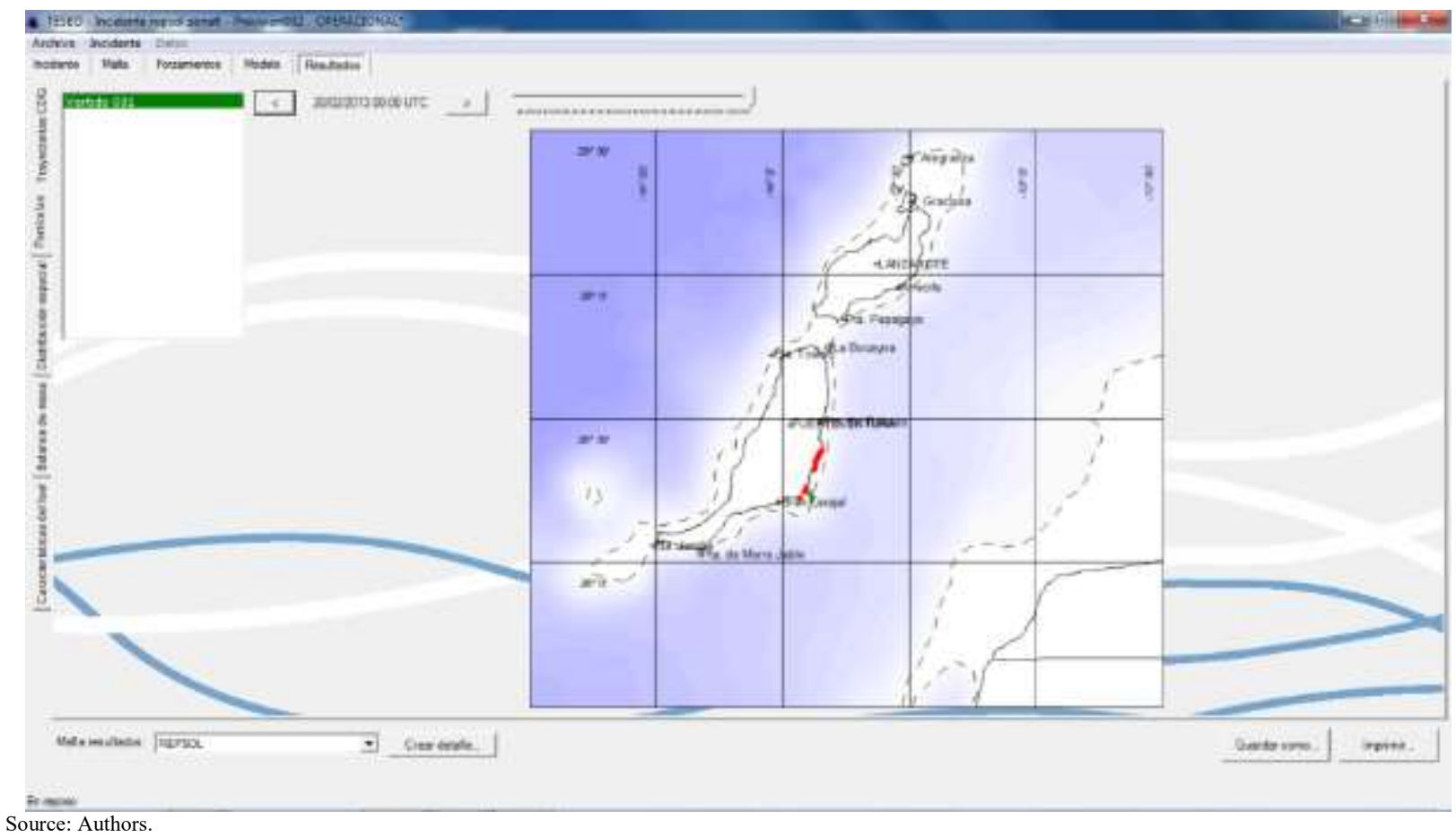

Figure 9: Spill location after 72 hours. Region Canarias 6. TESEO Model.

Figure 10 to Figure 13 show the probability (\%) of a certain marine area to be affected by a hydrocarbon spill going on for $72 \mathrm{~h}$.

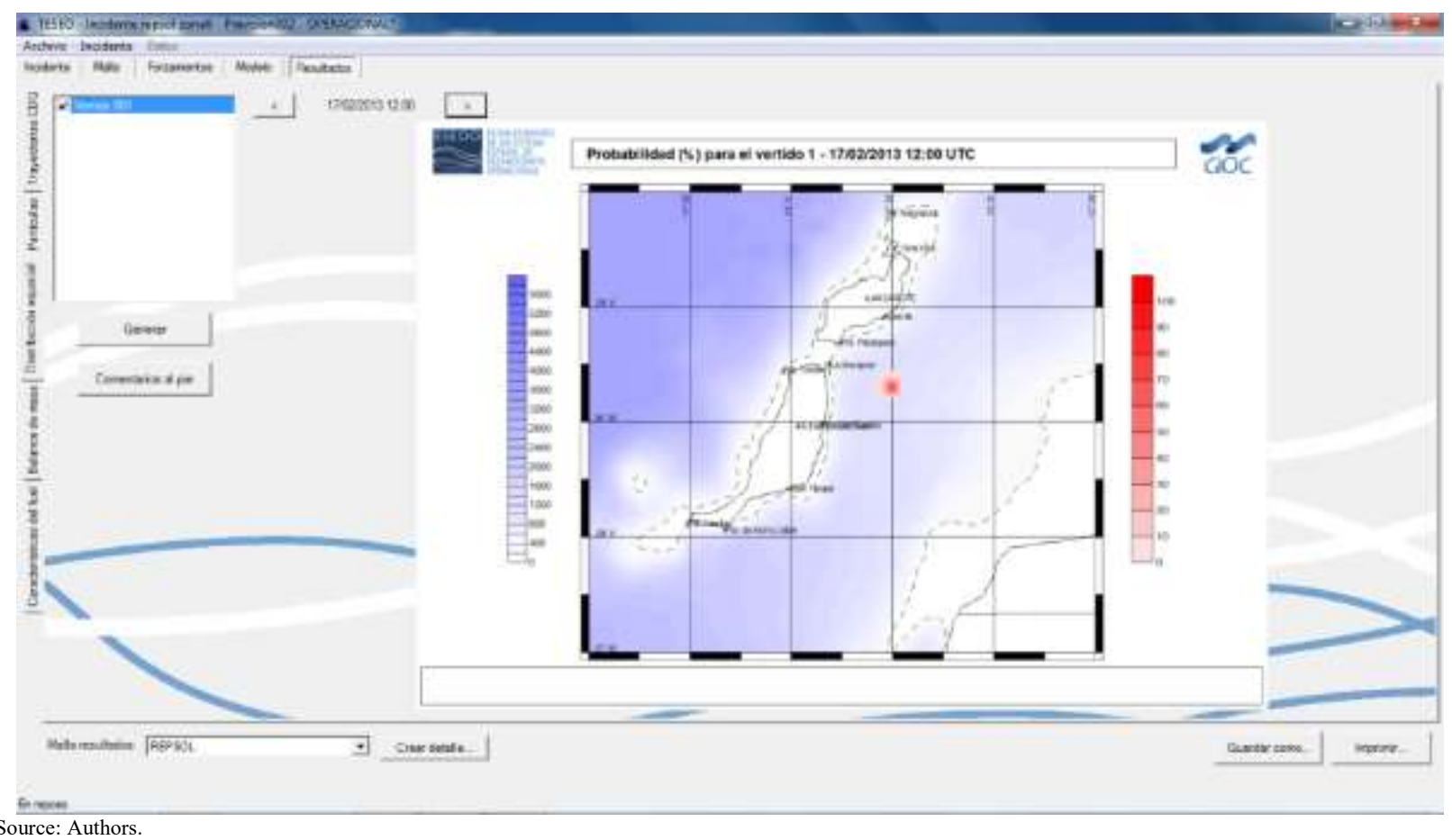

Nexo Revista Científica / Vol. 31, No. 01, pp. 47-63 / Junio 2018 
Figure 10- Probability of pollution after 12 hours. Region Canarias 6. TESEO Model.

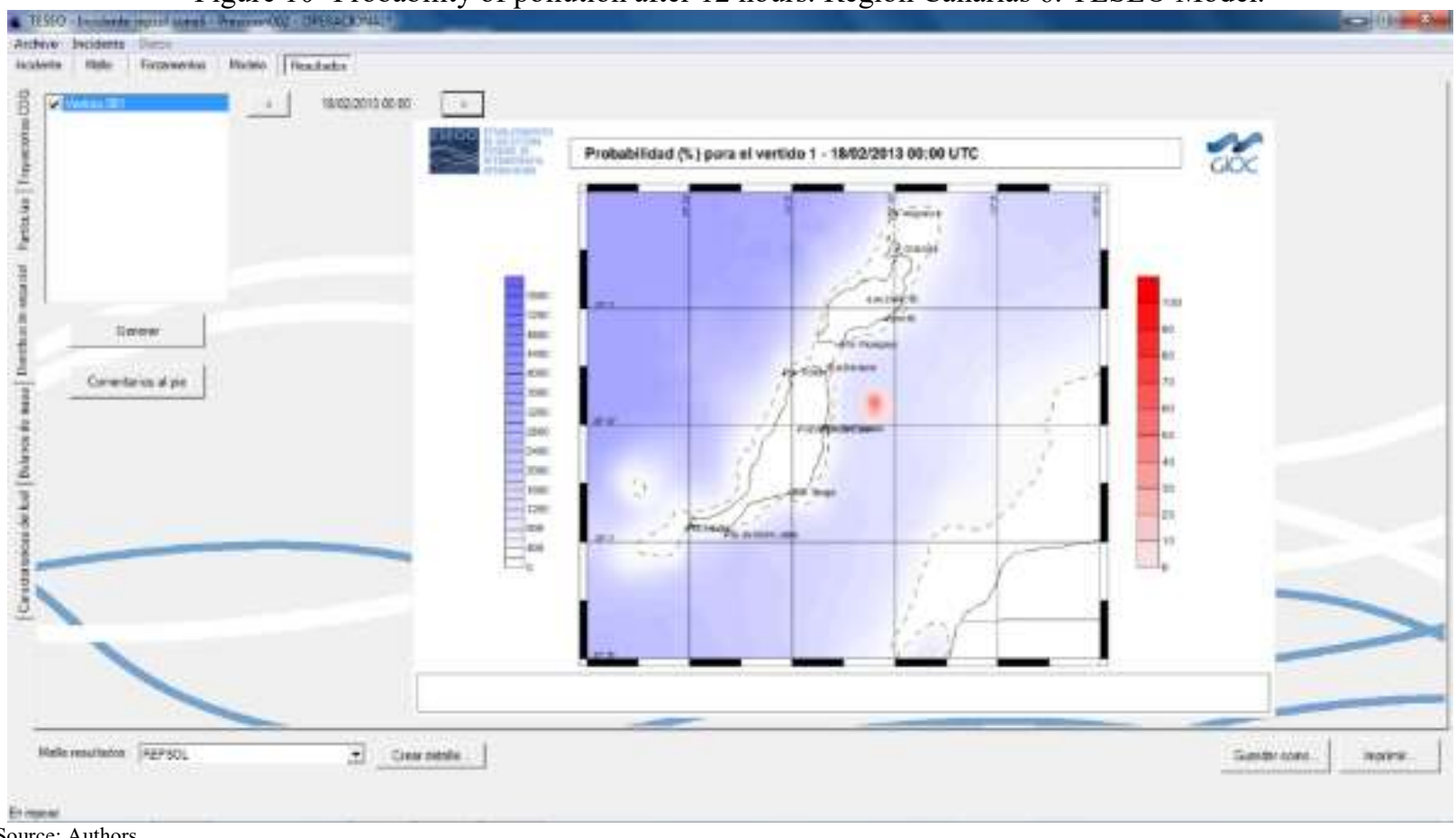

Figure 11- Probability of pollution after 36 hours. Region Canarias 6. TESEO Model.

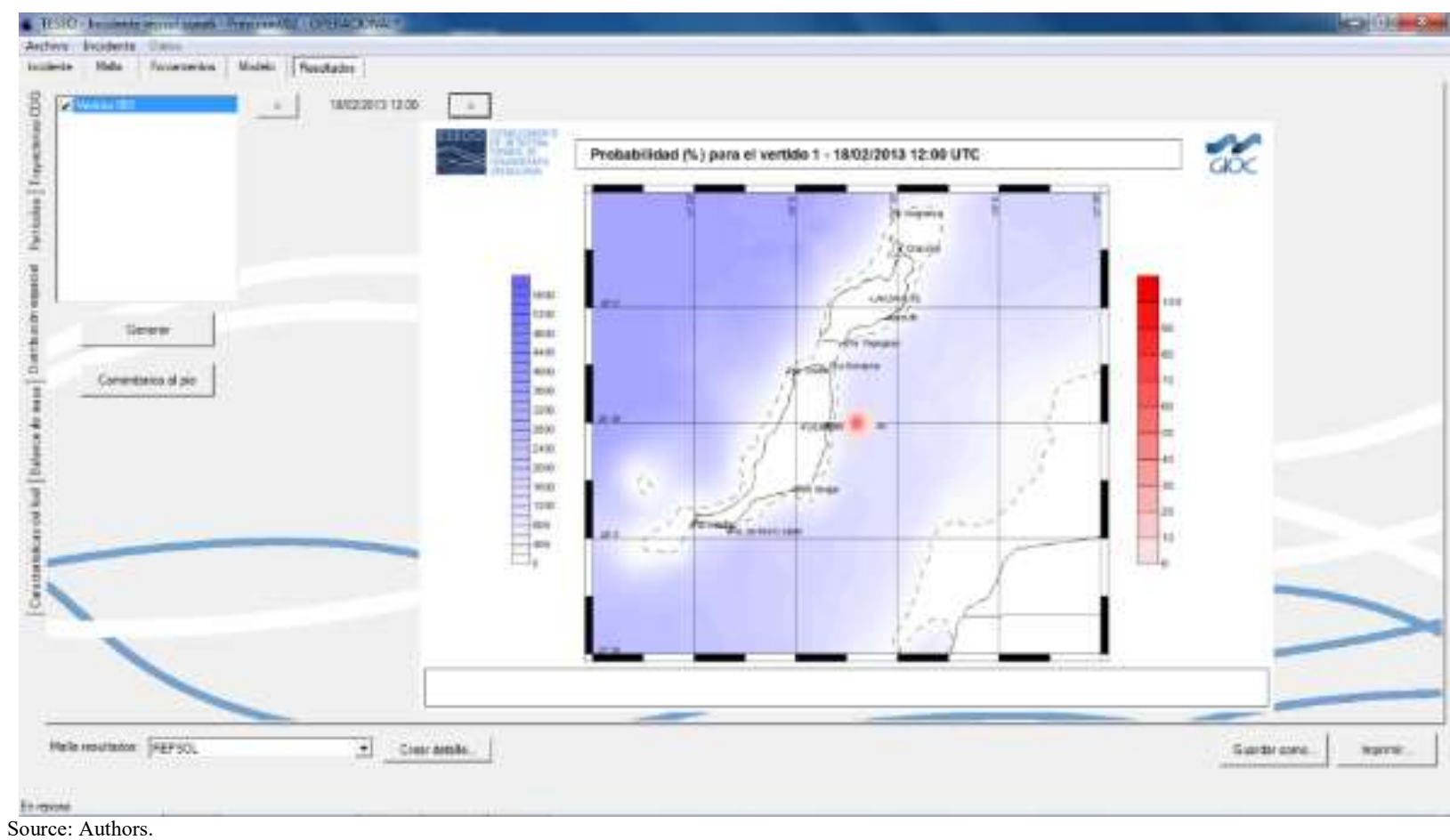

Figure 12- Probability of pollution after 60 hours. Region Canarias 6. TESEO Model. 
J.M. Calvilla et al.

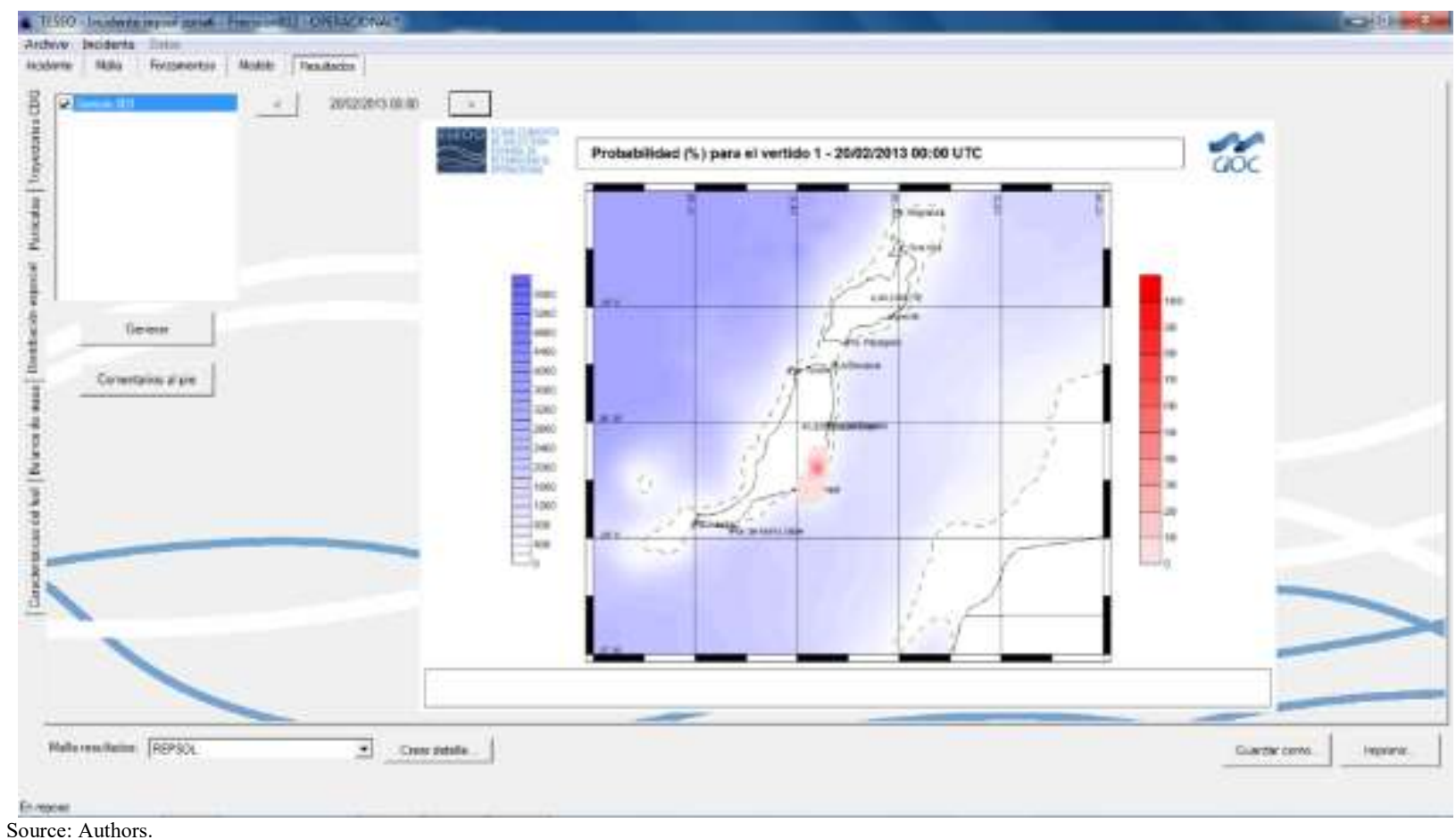

Figure 13- Probability of pollution after 72 hours. Region Canarias 6. TESEO Model.

Figure 14 shows the variation over time of the evaporated percentage.

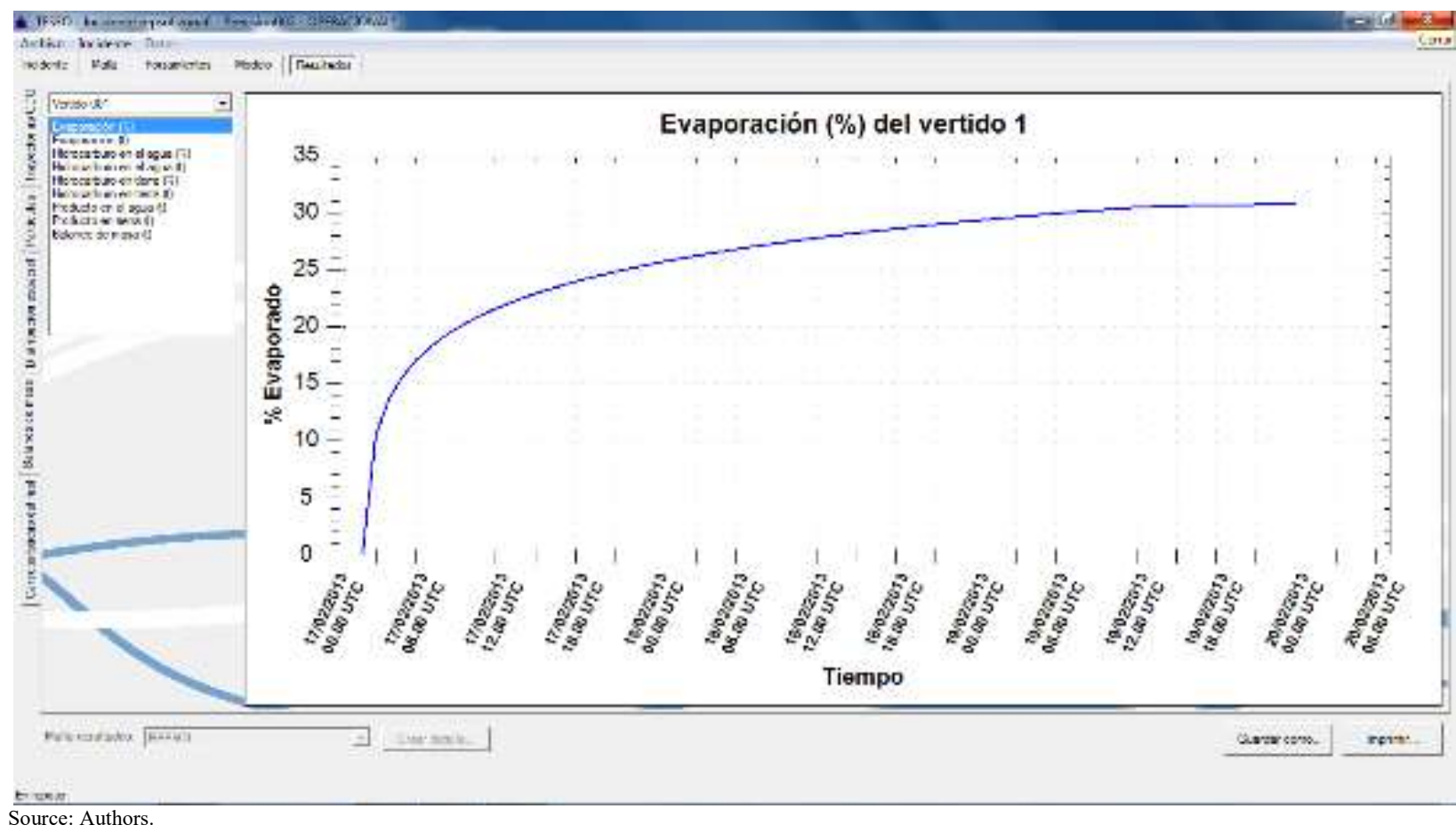

Figure 14: Variation over time of the evaporated percentage. Region Canarias 6. TESEO Model.

Figure 15 shows the variation over time of the hydrocarbon percentage in water. 
J.M. Calvilla et al.

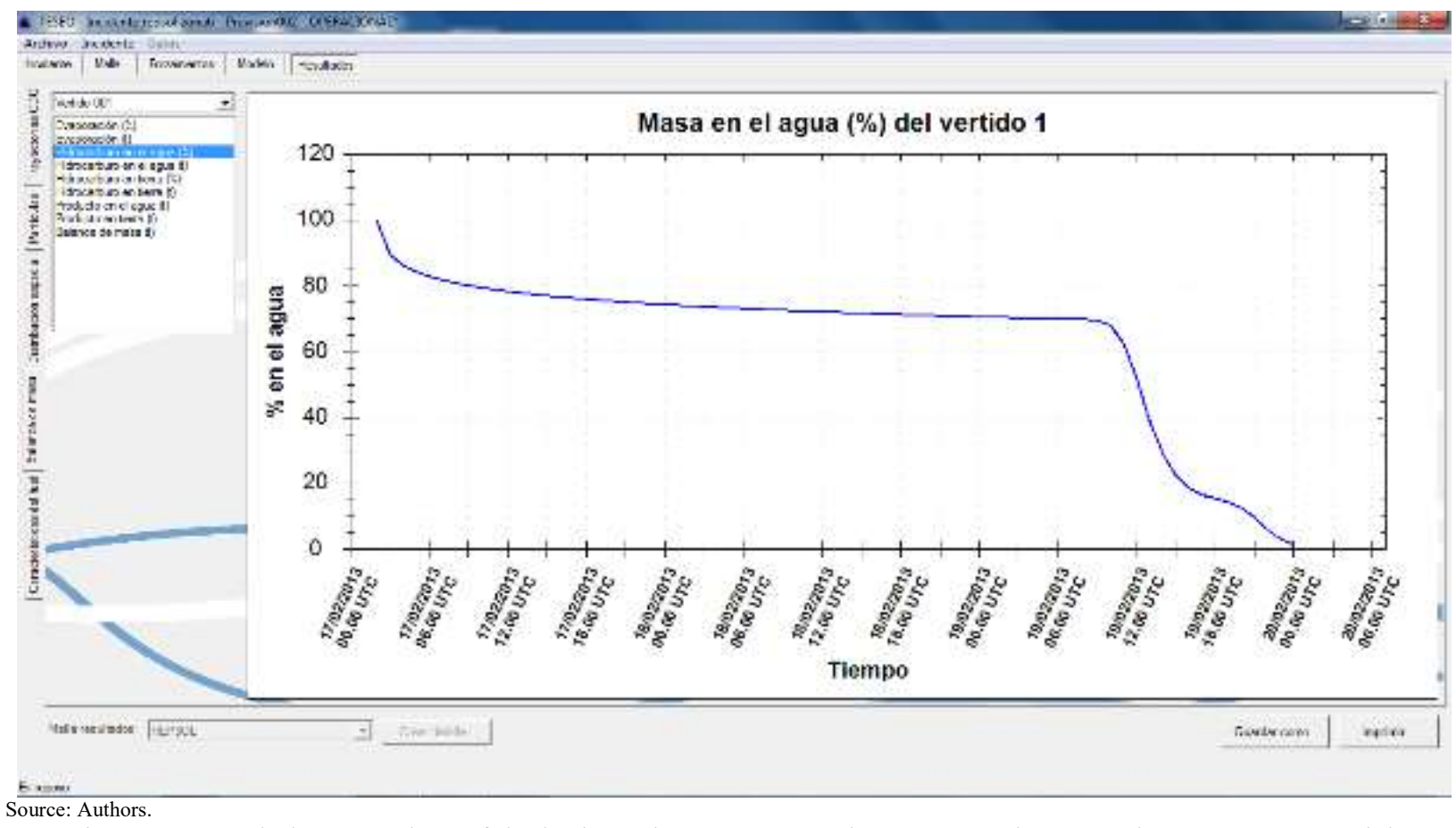

Figure 15 - Variation over time of the hydrocarbon percentage in water. Region Canarias 6. TESEO Model.

Figure 16 shows the variation over time of the percentage of the mass of hydrocarbons settled on the coast.

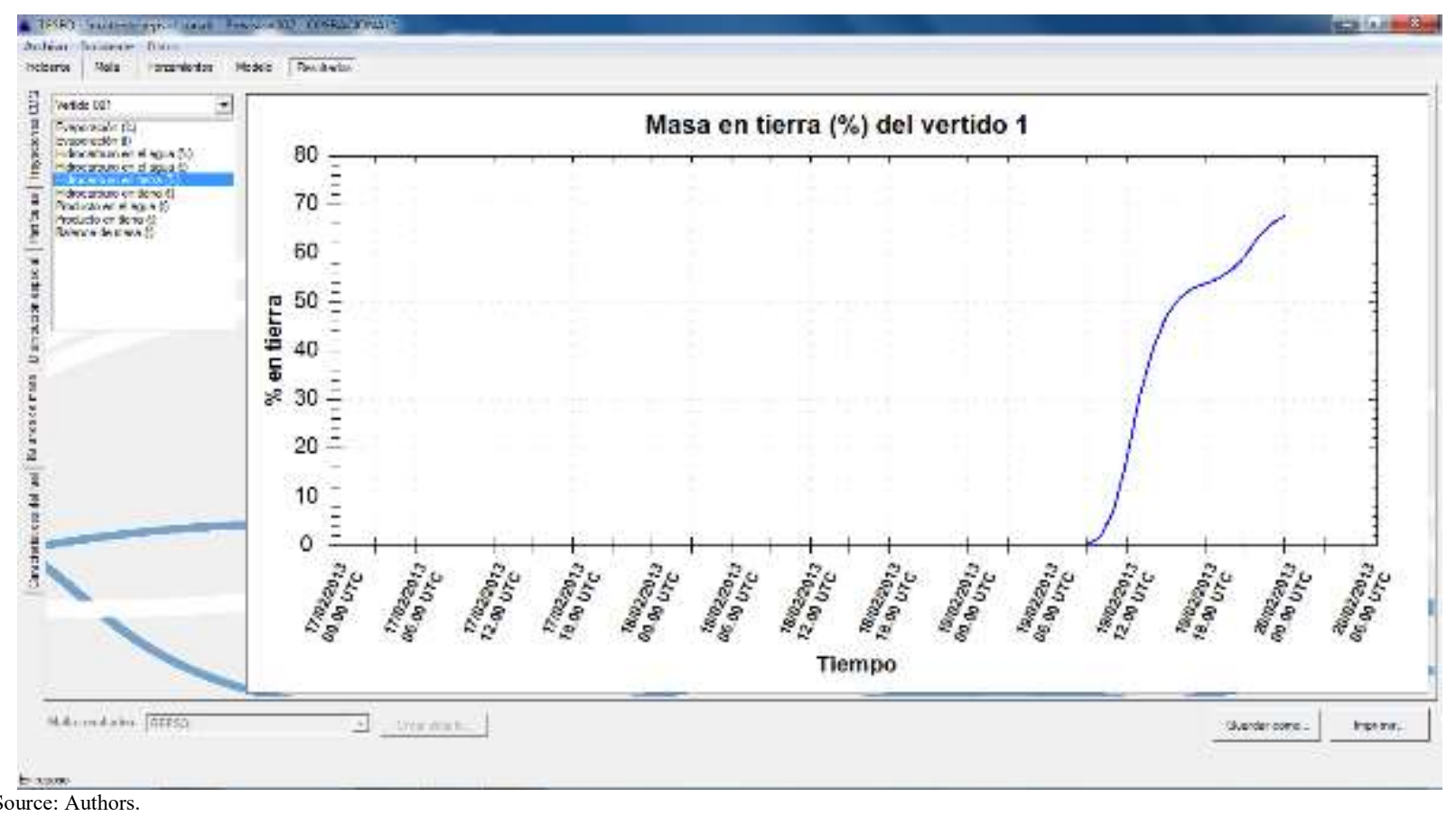

Figure 16: variation over time of the percentage of the mass of hydrocarbons settled on the coast. Region Canarias 6. TESEO Model.

Figure 17 shows the variation over time of the balance of spilled oil material. 
J.M. Calvilla et al.

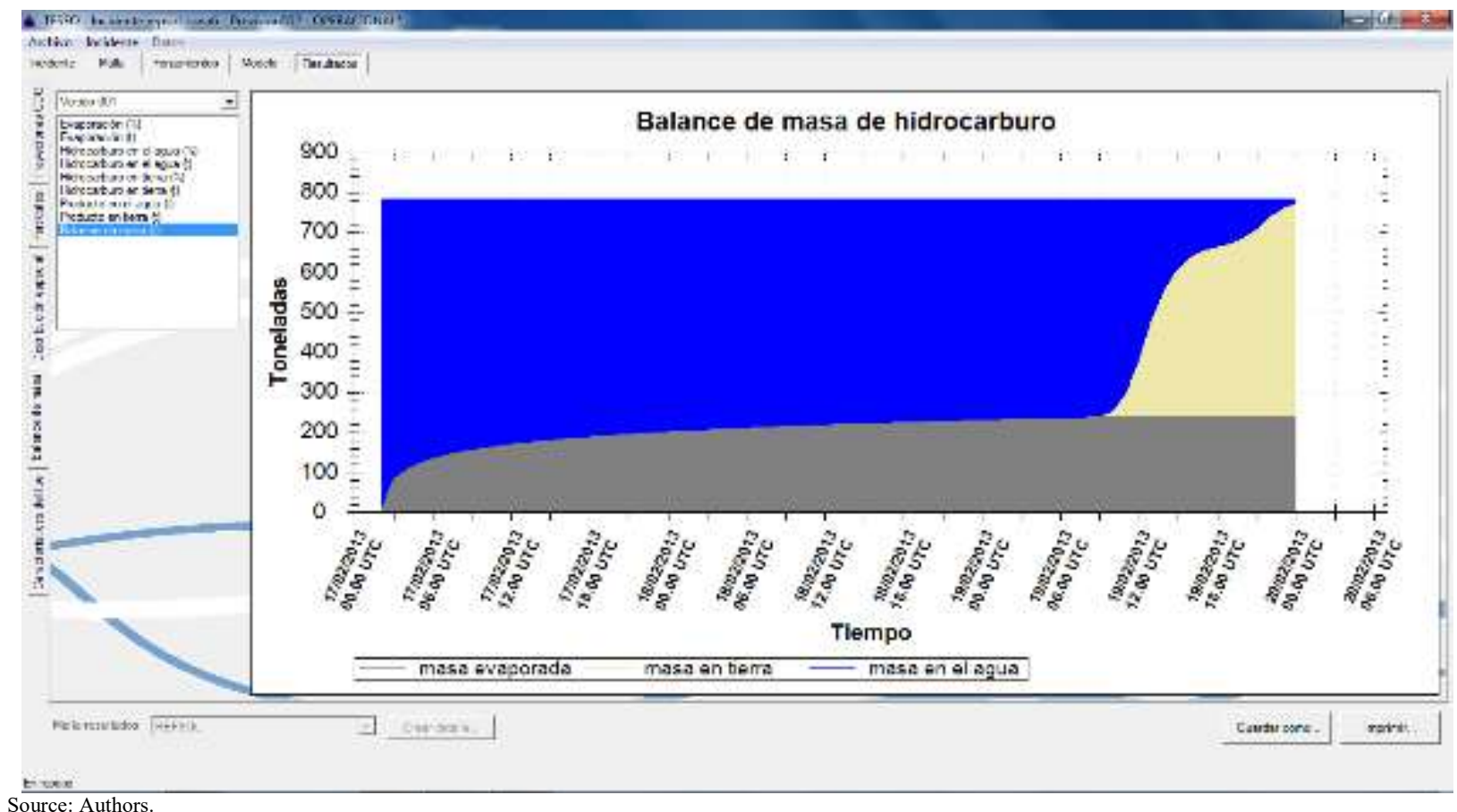

Figure 17: variation over time of the balance of spilled oil. Region Canarias 6. TESEO Model.

Figure 18 shows the variation over time of the density of the remaining hydrocarbon mixture.

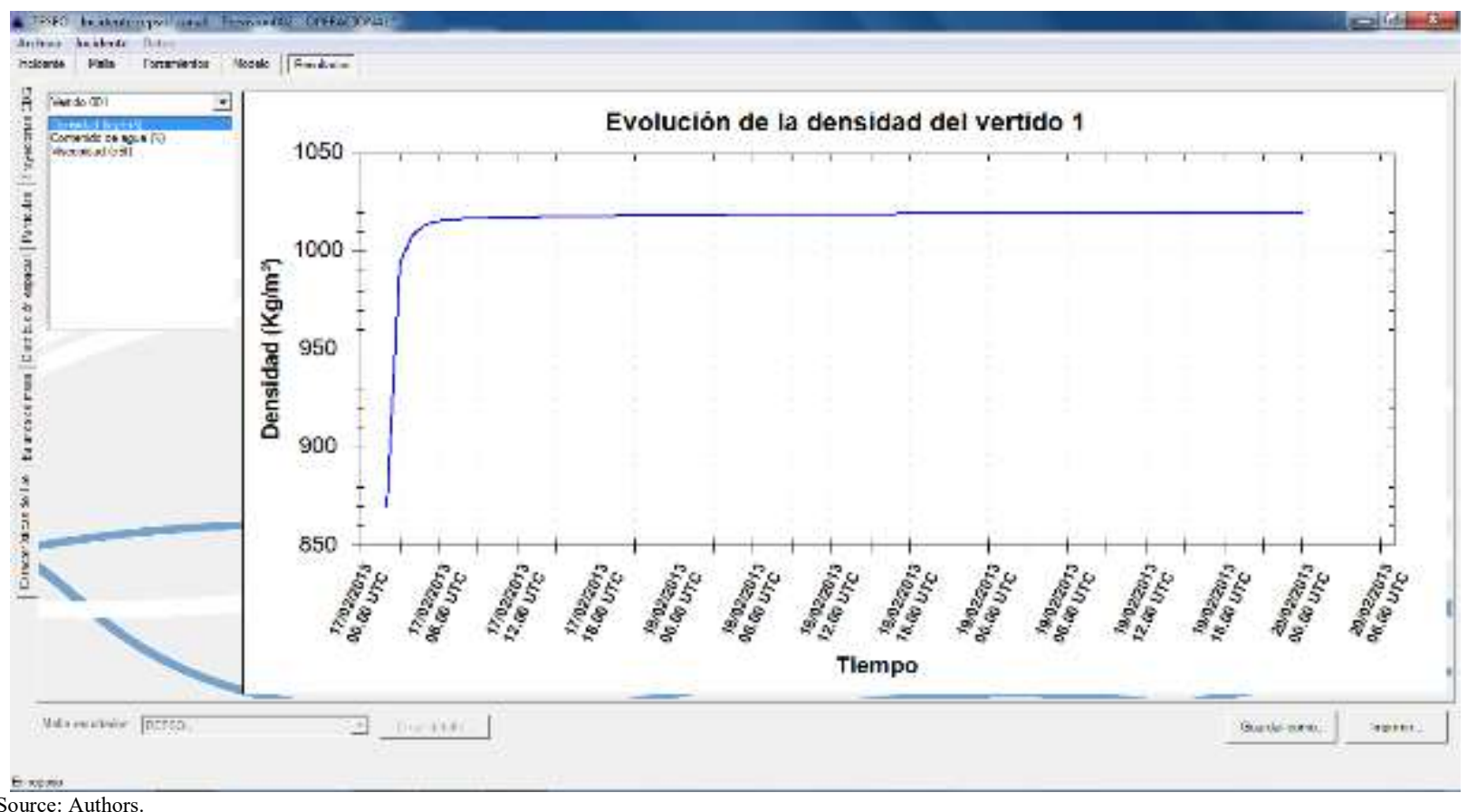

Figure 18: Variation over time of the density of the remaining hydrocarbon mixture. Region Canarias 6. TESEO Model.

Figure 19 shows the variation over time of the water content on the remaining oil. 
J.M. Calvilla et al.

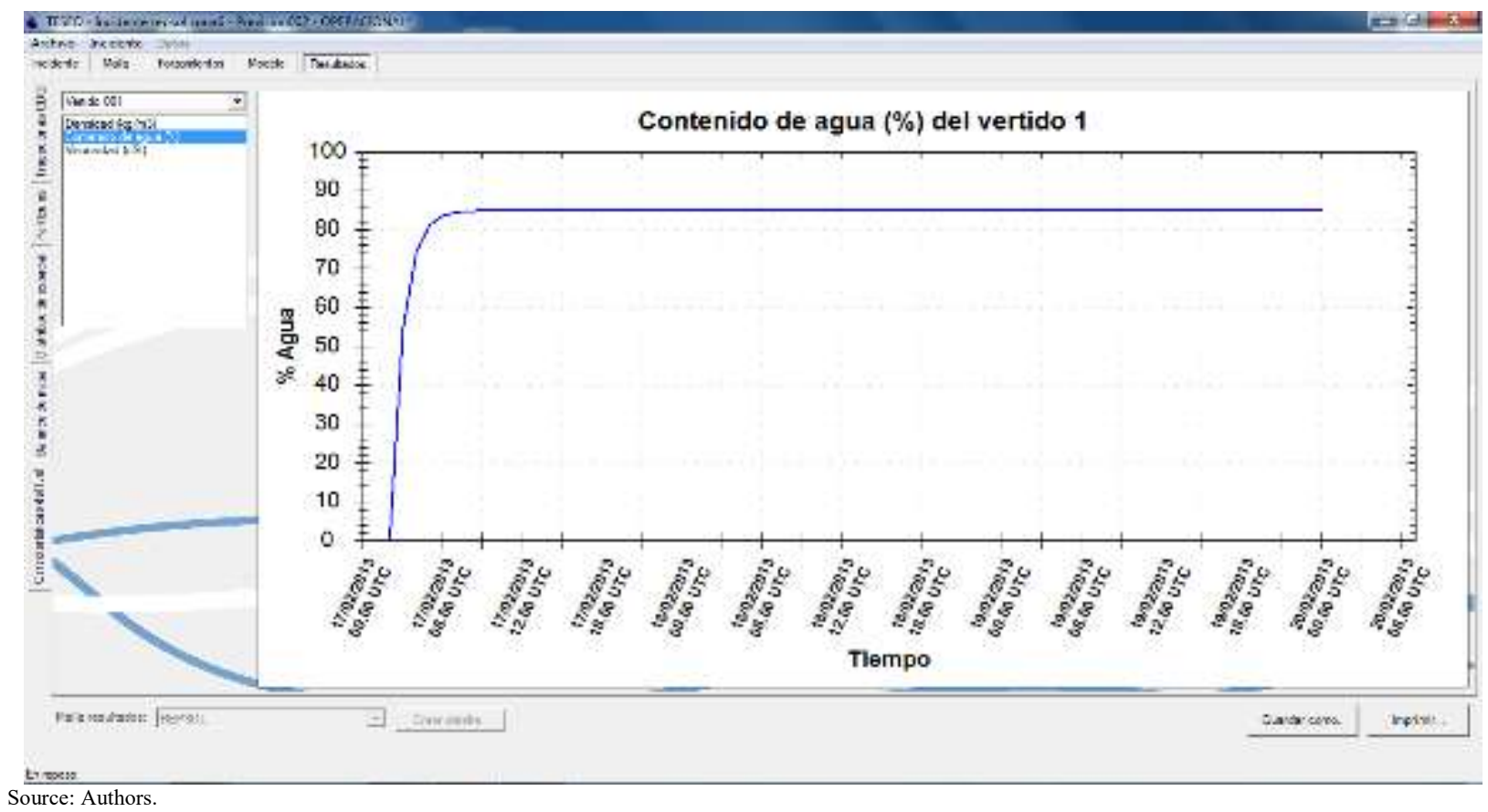

Figure 19: variation over time of the water content on the remaining oil. Region Canarias 6. TESEO Model.

Figure 20 shows the variation over time of the viscosity of the remaining hydrocarbons.

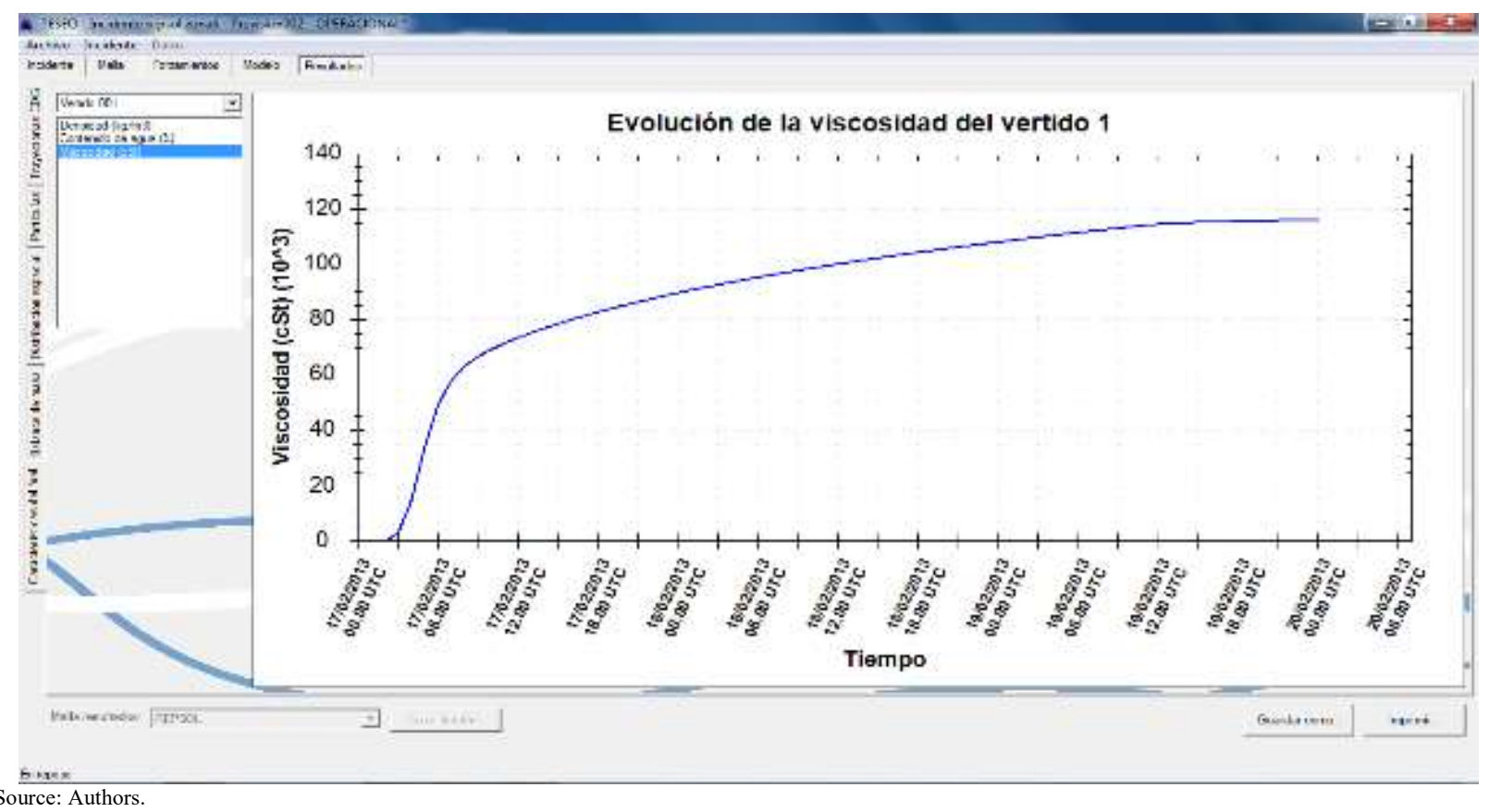

Figure 20: variation over time of the viscosity of the remaining hydrocarbons. Region Canarias 6. TESEO Model.

Figure 21 shows the path of the spill until it hits the coast of Fuerteventura. The impact point coordinates on the coast are the following: $28^{\circ} 18,6^{\prime} \mathrm{N} ; 13^{\circ} 53^{\prime} \mathrm{W}$. 


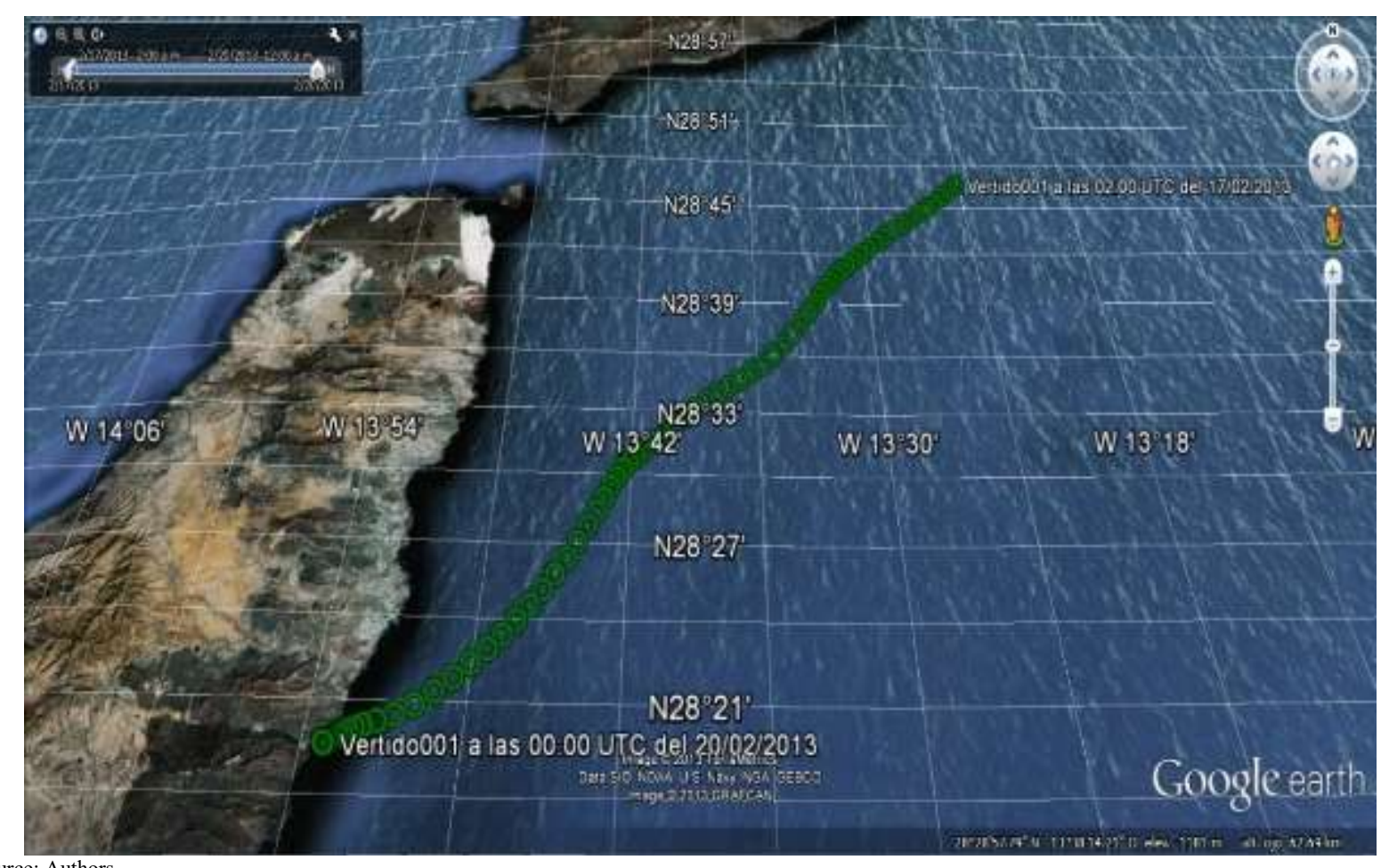

Figure 21: Path of the spill until it hits the coast of Fuerteventura. Region Canarias 6. TESEO Model.

\author{
Source: Authors.
}

\title{
3.2 RESULTS: TESEO Scenarios
}

Table 3 shows as an overview the results of the evolution of the spill by each of the scenarios tested with the TESEO Model.

\begin{tabular}{|c|c|c|c|c|c|c|c|c|}
\hline \multicolumn{9}{|c|}{ TESEO MODEL } \\
\hline \multicolumn{5}{|c|}{ INPUT MODEL } & \multicolumn{4}{|c|}{ RESULTS } \\
\hline 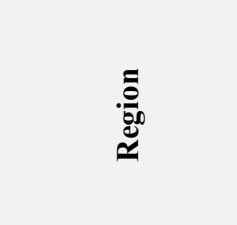 & $\underbrace{0}_{0}$ & 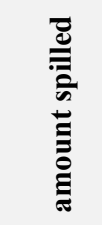 & 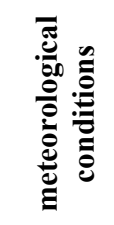 & 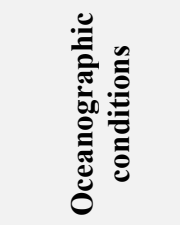 & 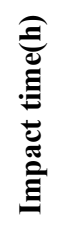 & 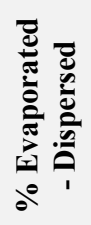 & 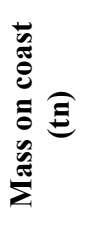 & 总 \\
\hline \multirow[t]{2}{*}{ CANARIAS 6} & Arabian Ligth & $960 \mathrm{~m}^{3}$ & AEMET & Puertos Estado & 57 & 31 & 530 & 27 \\
\hline & \multicolumn{8}{|c|}{$\begin{array}{l}\text { Sensitive Regions Affected: } \\
\text {-Fuerteventura } \\
\text { *Municipios: Tuineje, Antigua } \\
\text { *LIC: Monumento Natural Cuchillos de Vigán } \\
\text { *IBAS: Cuchilletes de Buenavista—arranco de la Torre- Los Alar, Macizo de Pozo Negro-Vigán } \\
\text { *ZEPA: Llanos y Cuchillos de Antigua, Pozo Negro } \\
\text { *Espacio Natural Protegido: : Monumento Natural: Cuchillos de Vigán }\end{array}$} \\
\hline \multirow{2}{*}{$\begin{array}{c}\text { Drilling Naranja } \\
\text { (Stochastic) } \\
\text { (D.H.) }\end{array}$} & Arabian Ligth & $222 \mathrm{~m}^{3}$ & AEMET & Puertos Estado & - & 34 & - & - \\
\hline & \multicolumn{8}{|c|}{ Sensitive Regions Affected: Possibly African Coast } \\
\hline \multirow{2}{*}{$\begin{array}{l}\text { Drilling Naranja } \\
\text { (Stochastic) }\end{array}$} & Arabian Ligth & $960 \mathrm{~m}^{3}$ & AEMET & Puertos Estado & - & 35 & - & - \\
\hline & \multicolumn{8}{|c|}{ Sensitive Regions Affected: ----------- } \\
\hline \multirow{2}{*}{$\begin{array}{c}\text { Drilling Sandía } \\
\text { (Stochastic) } \\
\text { (D.H.) }\end{array}$} & Arabian Ligth & $222 \mathrm{~m}^{3}$ & AEMET & Puertos Estado & - & 34 & - & - \\
\hline & \multicolumn{8}{|c|}{ Sensitive Regions Affected: } \\
\hline Drilling Sandía & Arabian Ligth & $960 \mathrm{~m}^{3}$ & AEMET & Puertos Estado & - & 35 & - & - \\
\hline
\end{tabular}


J.M. Calvilla et al.

\begin{tabular}{|c|c|c|c|c|c|c|c|c|}
\hline \multirow{3}{*}{$\begin{array}{c}\text { (Stochastic) } \\
\text { Drilling Forum Draa } \\
\text { (Stochastic) } \\
\text { (D.H.) }\end{array}$} & \multicolumn{8}{|c|}{ Sensitive Regions Affected: ------------ } \\
\hline & Arabian Ligth & $222 \mathrm{~m}^{3}$ & AEMET & Puertos Estado & 221 & 35 & 86 & 55 \\
\hline & \multicolumn{8}{|c|}{ Sensitive Regions Affected: African Coast } \\
\hline \multirow{2}{*}{$\begin{array}{l}\text { Drilling Forum Draa } \\
\text { (Stochastic) }\end{array}$} & Arabian Ligth & $960 \mathrm{~m}^{3}$ & AEMET & Puertos Estado & 147 & 35 & 540 & 24 \\
\hline & \multicolumn{8}{|c|}{ Sensitive Regions Affected: African Coast } \\
\hline \multirow{2}{*}{$\begin{array}{c}\text { Drilling Cabo Juby } \\
\text { (Stochastic) } \\
\text { (D.H.) }\end{array}$} & Arabian Ligth & $222 \mathrm{~m}^{3}$ & AEMET & Puertos Estado & 137 & 35 & 18 & - \\
\hline & \multicolumn{8}{|c|}{ Sensitive Regions Affected: African Coast } \\
\hline \multirow{2}{*}{$\begin{array}{c}\text { Drilling Cabo Juby } \\
\text { (Stochastic) }\end{array}$} & Arabian Ligth & $960 \mathrm{~m}^{3}$ & AEMET & Puertos Estado & 222 & 35 & 5 & - \\
\hline & \multicolumn{8}{|c|}{ Sensitive Regions Affected: African Coast } \\
\hline \multirow{2}{*}{$\begin{array}{l}\text { Drilling Essaouira } \\
\text { (Stochastic) (D.H.) }\end{array}$} & Arabian Ligth & $222 \mathrm{~m}^{3}$ & AEMET & Puertos Estado & 250 & 35 & - & - \\
\hline & \multicolumn{8}{|c|}{ Sensitive Regions Affected: African Coast } \\
\hline \multirow{2}{*}{$\begin{array}{l}\text { Drilling Essaouira } \\
\text { (Stochastic) }\end{array}$} & Arabian Ligth & $960 \mathrm{~m}^{3}$ & AEMET & Puertos Estado & 214 & 35 & 440 & 32 \\
\hline & \multicolumn{8}{|c|}{ Sensitive Regions Affected: African Coast } \\
\hline \multirow{2}{*}{$\begin{array}{l}\text { Drilling Sandía } \\
\text { Temporal Sur } \\
\text { (Deterministic) }\end{array}$} & Arabian Ligth & $960 \mathrm{~m}^{3}$ & AEMET & Puertos Estado & 125 & 33 & 560 & 50 \\
\hline & \multicolumn{8}{|c|}{$\begin{array}{l}\text { Sensitive Regions Affected: } \\
\text { Lanzarote } \\
\text { *Municipios: Arrecife, San Bartolomé, Tías, Yaiza } \\
\text { *LIC: Cagafrecho, Sebadales de Guasimeta } \\
\text { *ZEPA: Los Ajaches } \\
\text { * Espacio Natural Protegido: Monumento Natural Los Ajaches }\end{array}$} \\
\hline \multirow{2}{*}{$\begin{array}{l}\text { Drilling Chirimoya } \\
\text { Temporal Sur } \\
\text { (Deterministic) }\end{array}$} & Arabian Ligth & $960 \mathrm{~m}^{3}$ & AEMET & Puertos Estado & 98 & 35 & 290 & 62 \\
\hline & $\begin{array}{l}\text { Sensitive Region } \\
\text { Lanzarote } \\
\text { *Municipios: Tí } \\
\text { *LIC: Cagafrech } \\
\text { *ZEPA: Los Aja } \\
\text { * Espacio Natur } \\
\text { Fuerteventura } \\
\text { *Municipios: La } \\
\text { *LIC: Islote de I } \\
\text { *IBAS: Isla de I } \\
\text { *ZEPA: Dunas c } \\
\text { *Espacio Natura }\end{array}$ & $\begin{array}{l}\text { ffected: } \\
\text { Yaiza } \\
\text { es } \\
\text { rotegido: } \\
\text { iva } \\
\text { os, Sebad } \\
\text { os, Jable } \\
\text { orralejo } \\
\text { otegido: }\end{array}$ & $\begin{array}{l}\text { mento Nat } \\
\text { Corralejo } \\
\text { ralejo } \\
\text { le Lobos } \\
\text { Natural Is }\end{array}$ & $\begin{array}{l}\text { os Ajaches } \\
\text { ralejo } \\
\text { le Lobos, Parqu }\end{array}$ & & & & \\
\hline \multirow{2}{*}{$\begin{array}{l}\text { Drilling Cebolla } \\
\text { Temporal Sur } \\
\text { (Deterministic) }\end{array}$} & Arabian Ligth & $960 \mathrm{~m}^{3}$ & AEMET & Puertos Estado & 85 & 35 & 86 & 22 \\
\hline & $\begin{array}{l}\text { Sensitive Region } \\
\text { Lanzarote } \\
\text { *Municipios: Ha } \\
\text { *Reserva Marin } \\
\text { *LIC: Los Jame } \\
\text { IBAS: Los Islote } \\
\text { *ZEPA: Islotes } \\
\text { *Espacio Natura }\end{array}$ & $\begin{array}{l}\text { ffected: } \\
\text { Archipie } \\
\text { Lanzaro } \\
\text { La Coror } \\
\text { e Lanzarc } \\
\text { Norte de } \\
\text { otegido: }\end{array}$ & $\begin{array}{l}\text { inijo. } \\
\text { hipiélago } \\
\text { cos de Fan } \\
\text { ote y Fama } \\
\text { nento Natu }\end{array}$ & a, Los Islotes, Se & aral $\mathrm{Al}$ & acios & & \\
\hline \multirow{2}{*}{$\begin{array}{c}\text { Drilling Cabo Juby } \\
\text { Temporal Sur } \\
\text { (Deterministic) }\end{array}$} & Arabian Ligth & $960 \mathrm{~m}^{3}$ & AEMET & Puertos Estado & 138 & 34 & 560 & 39 \\
\hline & \multicolumn{8}{|c|}{$\begin{array}{l}\text { Sensitive Regions Affected: } \\
\text { Lanzarote } \\
\text { *Municipios: Arrecife, San Bartolomé, Tías, Yaiza } \\
\text { *LIC: Sebadales de Guasimeta, Cagafrecho } \\
\text { *ZEPA: Los Ajaches } \\
\text { * Espacio Natural Protegido: Monumento Natural Los Ajaches }\end{array}$} \\
\hline & Nota: & H.: Dee & Horizon & litions (Gulf & & & & \\
\hline
\end{tabular}

Source: Authors.

Table 3: Summary of the evolution of the spill by each of the scenarios tested with the TESEO Model.

\section{CONCLUSIONS}

We have analyzed the results of deterministic and stochastic simulations for a possible accidental oil spill during underwater oil exploration in the eastern region of the Canary Islands waters.

The potential spill trajectories have been analyzed using TESEO model to evaluate the impact on the coast. Real data from National Meteorological Agency and Puertos del Estado was used to accomplish the description of wind, water flows and waves in the area. 
From the results of these cases, it can be concluded that alarge amount of oil spill stays in the water column. Likewise, exploratory research in Morocco waters does not exempt the Canary Islands of being affected by oil spill. The weathering process intervene remarkably. From the viewpoint of impact and drift length probability we observe a moderate-high impact on the coast and sensitivity regions (Fuerteventura and Lanzarote). As an important consequence, the cleaning and coast restoration becomes more difficult and compromising the complex marine ecosystem and local economies based on tourism.

\section{BIBLIOGRAPHY}

ABASCAL, e. (2008). Description and Application of the Operational Oil Spill Forecast System TESEO. International Oil Spill Conference.

BERGUEIRO, J.R. et al. (2001). La Gestión de los Derrames de Hidrocarburos en el Mar. Palma de Mallorca: Ref. I.S.B.N.: 84-699-60571.

BERGUEIRO (2004). BERGUEIRO LÓPEZ, J. R., SERRA SOCÍAS, F., et al. Gestión Integrada de Zonas Costeras Ante Vertidos de Hidrocarburos en el Mar Balear. Palma de Mallorca: I.S.B.N.: 84 - 688 -8919 - 9. Depósito Legal: PM 2349 - 2004. Área de Ingeniería Química. Facultad de Ciencias. Universidada de las Islas Baleares.

BERGUEIRO (2009). BERGUEIRO LÓPEZ, J.R. El Modelo S.O.N.I.A: Su Aplicación a la Gestión de Derrames de Hidrocarburos en el Mar. I Jornadas Nacionales de Seguridad y Contaminación Marina. Escuela Técnica Superior de Náutica, Máquinas y Radioelectrónica Naval .ULL.

ESEOO Project. Establecimiento de un Sistema Español de Oceanografía Operacional (ESEOO). Ministerio de Ciencia y Tecnología (2004-2007).

FAY, J., (1969). The Spread of Oil Slicks on calm sea. Oil on the sea. Ed. Hoult, Plenum Press.

FAY, J., (1971). Physical processes in the spread of oil on a water surface. Proc. of the Jount Conf. on Prevention and Control of Oil Spill. American Petroleum Institute, Washington, DC, 463-467.

LEHR ET AL. (1984). Lehr, W.J., Fraga, R., Belen, M., Cekirge, H., 1984. A new technique to estimate initial spill size using a modified Fay-type spreading formula. Marine Pollution Bulletin 15 (9), 326-329.

MACKAY (1980). Mackay, D., Paterson, S., Trudel, K., 1980. A Mathematical Model of Oil Spill Behaviour. Environmental Protection Service, Fisheries and Environment Canada, EE-7, 39 p.39 pp.

SANTAMARÍA, R. M. (2006). Los Modelos de Deriva en la Predicción de Vertidos. A Coruña: 1as Jornadas Científico-Técnicas de Lucha Contra la Contaminación Marina.

STIVER, W., \& MACKAY, D. (1984). Evaporation Rate of Spills of Hydrocarbons and Petroleum Mixtures. Environment Science \& Technology.

\section{SEMBLANZA DE LOS AUTORES}

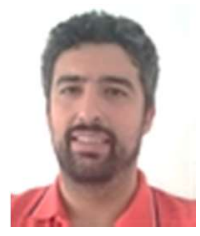

J.M. Calvilla es Licenciado en Física y Doctor en Toxicología, Contaminación y Seguridad en el Transporte Marítimo por la Universidad de La Laguna (España). Su área de investigación está centrada en la Contaminación Marina por Hidrocarburos, la modelización de vertidos accidentales y la elaboración de Planes de Contingencias. Investigador del Grupo I+D CONSEMAR (Contaminación y Seguridad Marina),Universidad de La Laguna. 